\title{
Synthesis of $\mathrm{LiCoPO}_{4}$ Powders as a High-Voltage Cathode Material via Solvothermal Method
}

\author{
Jianhuang Ke, Yu Han, Kai Xie \\ College of Aerospace Science and Engineering, National University of Defense Technology, Changsha, China \\ Email: qwe512993975@163.com
}

How to cite this paper: Ke, J.H., Han, Y. and Xie, K. (2017) Synthesis of $\mathrm{LiCoPO}_{4}$ Powders as a High-Voltage Cathode Material via Solvothermal Method Synthesis of LiCoPO4 Powders as a High-Voltage Cathode Material via Solvothermal Method. Journal of Power and Energy Engineering, 5, 21-27.

https://doi.org/10.4236/jpee.2017.512004

Received: November 1, 2017

Accepted: November 14, 2017

Published: November 21, 2017

\begin{abstract}
Lithium cobalt phosphate $\left(\mathrm{LiCoPO}_{4}, \mathrm{LCP}\right)$, having a high operating potential (4.8 V vs. $\left.\mathrm{Li} / \mathrm{Li}^{+}\right)$, a flat voltage profile and a good theoretical capacity (167 $\mathrm{mAh} / \mathrm{g}$ ), is considered a promising cathode material for improving the energy density of lithium-ion batteries (LIBs) [1] [2]. Here we report a category of method for synthesizing LCP, the solvothermal (ST) method with a binary solvent (deionized water: ethyl alcohol $=1: 1$ ), controlling the concentration of cobalt ion in $0.05 \mathrm{~mol} / \mathrm{L}(\mathrm{ST}-0.05)$ and $0.25 \mathrm{~mol} / \mathrm{L}$ (ST-0.25). The material phase was apparently identified via X-ray diffraction (XRD). Observed by scanning electron microscopy (SEM), the grain size of LCP powders synthesizing by solvothermal method with two kinds of the concentration of cobalt ion were $400 \times 400 \times 1000 \mathrm{~nm}$ cuboids (ST-0.05) and $150 \times 150 \times 250 \mathrm{~nm}$ hexagonal prisms containing nanoparticles (ST-0.25), respectively. Discharge capacities of LCP were $76.0 \mathrm{mAh} / \mathrm{g}$ (ST-0.05) and $94.5 \mathrm{mAh} / \mathrm{g}$ (ST-0.25), in the first cycle at $0.1 \mathrm{C}$, respectively.
\end{abstract}

\section{Keywords}

Lithium Cobalt Phosphate, Solvothermal Synthesis, High-Voltage Cathode, Lithium-Ion Batteries

\section{Introduction}

Since the cathode material of Lithium iron phosphate $\left(\mathrm{LiFePO}_{4}\right.$, LFP) was first reported, lithium transition-metal phosphates [2], including the manganese (LMP), cobalt (LCP) or nickel (LNP) based phospho-olivines [3], have been receiving increasing attention as alternative cathode materials for lithium-ion batteries (LIBs) [4]. Compared to LFP (theoretical capacity: $167 \mathrm{mAh} / \mathrm{g}$, gravimetric energy density: $580 \mathrm{Wh} / \mathrm{kg}$ ) [5], the high-voltage cathode material LCP, which operates at $4.8 \mathrm{~V} \mathrm{[6]}$ and shows a theoretical capacity of $166.56 \mathrm{mAh} / \mathrm{g}$, provides 
the high operating voltage to increase the gravimetric energy density to 800 $\mathrm{Wh} / \mathrm{kg}$, about $40 \%$ higher than LFP, so that might bring a significant improvement for LIBs [7].

Recently, there were many kinds of approach to synthesizing LCP powders, containing CAM sol-gel [8], hydrothermal method [9], solvothermal method [10] [11], polyol process [12], solid-phase method [13], microwave method [14] and so on. Among these, the mainstream method were hydrothermal method that synthetic crystals at relatively low reaction temperature and uniformity of product composition, phase and microstructure.

\section{Experiment}

$\mathrm{LiOH} \cdot \mathrm{H}_{2} \mathrm{O}(\geq 95 \%, \mathrm{AR}), \mathrm{CoSO}_{4} \cdot 7 \mathrm{H}_{2} \mathrm{O}(\geq 99.5 \%, \mathrm{AR})$ and $\mathrm{H}_{3} \mathrm{PO}_{4}(\geq 85 \mathrm{wt} \%$ in $\mathrm{H}_{2} \mathrm{O}$ ) were used in a Li: Co: $\mathrm{P}$ molar ratio of 3:1:1 and $2.5 \mathrm{~g} / \mathrm{L}$ ascorbic acid $(\geq 99.7 \%, A R)$ was added as a reducing agent, controlling the concentration of cobalt ion in $0.05 \mathrm{~mol} / \mathrm{L}$ (ST-0.05) and $0.25 \mathrm{~mol} / \mathrm{L}$ (ST-0.25). The raw materials were dissolved in a binary solvents composed of deionized water and ethyl alcohol, controlling the initial PH value of solution was 8.5. The as-prepared suspension was poured into a stainless autoclave and sealed, hydrothermally treated at $220^{\circ} \mathrm{C}$ for $5 \mathrm{~h}$. Testing the remaining solutions, the $\mathrm{PH}$ of the solvent environment after the reaction were 6.57 (ST-0.05) and 3.81 (ST-0.25). After natural cooling, the reaction products were washed several times with deionized water and ethanol to get rid of any remaining precursors or organic products. The recovered powders were heated to $700^{\circ} \mathrm{C}$ with a rate of $5^{\circ} \mathrm{C} / \mathrm{min}$ and held at the temperature for $60 \mathrm{~min}$ under argon atmosphere.

The LCP electrode was made by mixing $80 \mathrm{wt} \%$ of the as-prepared LCP powder, $10 \mathrm{wt} \%$ acetylene black (Timal) and $10 \mathrm{wt} \%$ polyvinylidene difluoride (PVdF, Arkema) in N-methyl-2-pyrrolidone (NMP), and then, was painted onto a thin $\mathrm{Al}$ foil and dried at $100^{\circ} \mathrm{C}$ for $12 \mathrm{~h}$. The LCP composite electrode $(15 \mathrm{~mm}$ in diameter) was set in a coin cell 2016 with a mixture of ethylene carbonate and ethyl methyl carbonate (volume ratio $=3: 7$ ) containing $1.2 \mathrm{~mol} \cdot \mathrm{dm}^{-3} \mathrm{LiPF}_{6}$ as an electrolyte, with lithium metal as a negative electrode and with polyethylene film as a separators (PE, Celgard 2400). Galvanostatic cycling was performed between $3.5 \mathrm{~V}$ and $5 \mathrm{~V}$ for 5 cycles at $\mathrm{C} / 10$ (C rates based on a theoretical capacity of 167 $\mathrm{mAh} / \mathrm{g}$ ). CV measurements were performed up to three cycles at a scanning rate of $0.05 \mathrm{mV} / \mathrm{s}$ for a voltage range of $3.0 \mathrm{~V}$ to $5.1 \mathrm{~V}$.

$\mathrm{X}$-ray diffraction (XRD) data were collected on a SIEMENS-500 diffractometer using $\mathrm{Cu} \mathrm{Kal}$ radiation $(\lambda=1.54 \AA)$, measured in a $2 \theta$ range of $10^{\circ}-80^{\circ}$ (tube current: $200 \mathrm{~mA}$; voltage: $40 \mathrm{kV}$; sweep rate: $7^{\circ} / \mathrm{min}$ ). Scanning electron microscopy (SEM) image was performed on a HITACHI S-4800 Field Emission Scanning Electron Microscope.

\section{Results and Discussion}

The X-ray diffraction (XRD) patterns of the as-prepared products were pre- 
sented in Figure1 (a) displayed that the XRD peaks correspond to the standard PDF (85-0002) of olivine structure with space group Pnma (62) which means $\mathrm{LiCoPO}_{4}$ synthesized by solvothermal synthesis with the concentration of cobalt ion in $0.05 \mathrm{~mol} / \mathrm{L}$ was successfully acquired without any undesirable impurities. Figure 1(b) shown that the powders synthesized by solvothermal synthesis with the concentration of cobalt ion in $0.25 \mathrm{~mol} / \mathrm{L}$ were mainly LCP granule, containing some other unexpected impurities $\left(\mathrm{Co}_{11}\left(\mathrm{HPO}_{3}\right)_{8}(\mathrm{OH})_{6}\right)$. The concentration of raw materials in ST-0.25 was obvious higher than in ST-0.05. During the process of Solvothermal, the excessive concentration of phosphoric acid locally would give rise to the two steps dehydration decomposition under high reaction temperature and pressure conditions. The phosphoric acid dehydration decomposed to pyrophosphoric acid firstly, and then further decomposed to metaphosphoric acid. The process of dehydration decomposition as follows:

$$
\begin{aligned}
2 \mathrm{H}_{3} \mathrm{PO}_{4} & \rightarrow \mathrm{H}_{4} \mathrm{P}_{2} \mathrm{O}_{7}+\mathrm{H}_{2} \mathrm{O} \\
\mathrm{H}_{4} \mathrm{P}_{2} \mathrm{O}_{7} & \rightarrow 2 \mathrm{HPO}_{3}+\mathrm{H}_{2} \mathrm{O}
\end{aligned}
$$

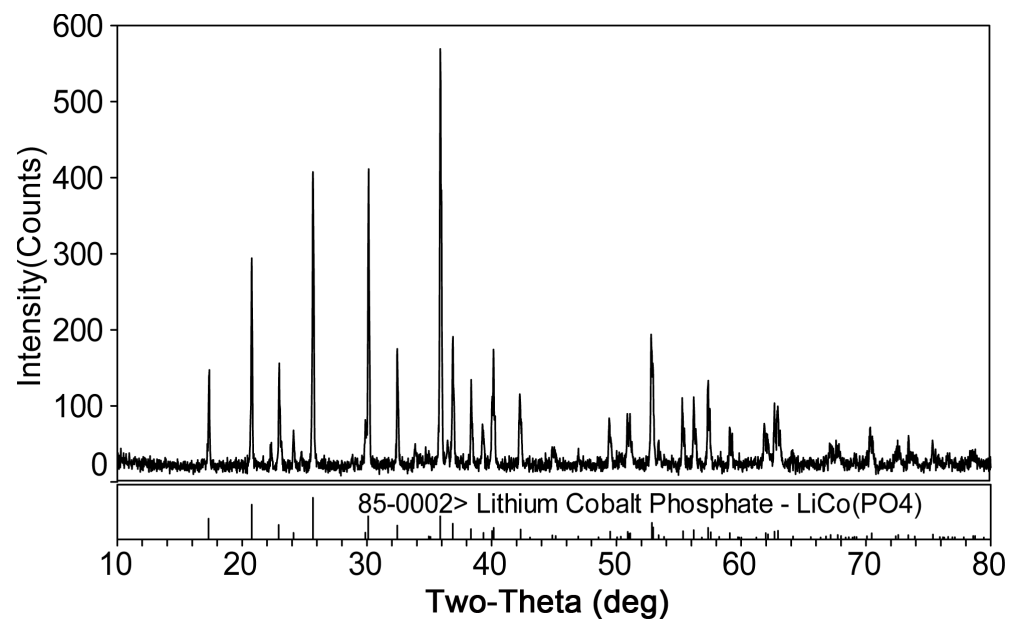

(a)

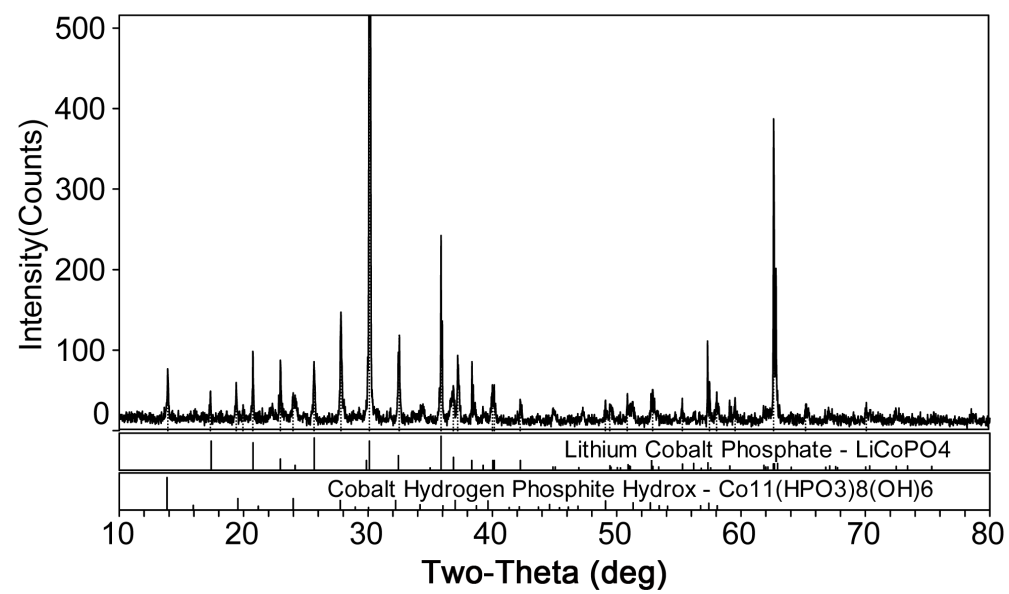

(b)

Figure 1. XRD patterns of $\mathrm{LiCoPO}_{4}$ synthesized via (a) ST-0.05 and (b) ST-0.025. 
Figure 2 displayed the scanning electron microscopy (SEM) of the as-prepared powders before heat treatment. The result verified that powders with an average size of $150 \times 150 \times 250 \mathrm{~nm}$ for hexagonal prisms synthesizing by ST- 0.25 were obviously smaller than with $400 \times 400 \times 1000 \mathrm{~nm}$ cuboids synthesizing by ST-0.05. That was attributed to the higher concentration of cobalt ion, providing more necessarily nucleus for the nucleation and growth of the crystal granules. In addition, powders synthesizing by the both methods contained some other small granule, identified as the impurities and uncompleted crystallization granule. That would be solved effectively by the following heat treatment. The powders which formed by ST apparently had well dispersity, giving the credit to the binary solvent (deionized water: ethyl alcohol $=1: 1$ ) that homogeneous controlled the grain and morphology by selective adsorption mechanism. During the process of crystallization, the solvent molecules would be adsorbed on some specific surfaces of crystal granules selectively, limiting the growth of grain in some direction. Different solvents would express different results of selection.

Figure 3 revealed charge and discharge curves of LCP (ST). Discharge capacities of LCP were $76 \mathrm{mAh} / \mathrm{g}$ (ST-0.05) and $94.5 \mathrm{mAh} / \mathrm{g}$ (ST-0.25) in the first cycle at $0.1 \mathrm{C}$, respectively. The discharge voltage flat of LCP, acquiring from charge-discharge curves, were about 4.72 V (ST-0.05) and 4.67 V (ST-0.25), corresponding to lithium insertion into $\mathrm{CoPO}_{4}$ to form a mixture of $\mathrm{Li}_{0.67} \mathrm{CoPO}_{4}$ and $\mathrm{LiCoPO}_{4}$ phases that was exactly opposite during the process of charge.

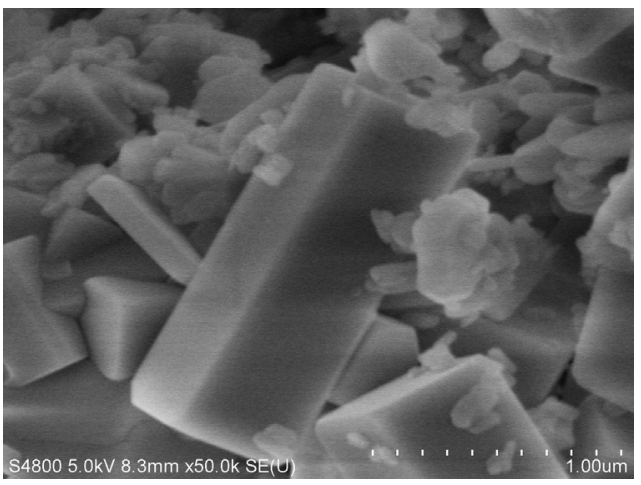

(a)

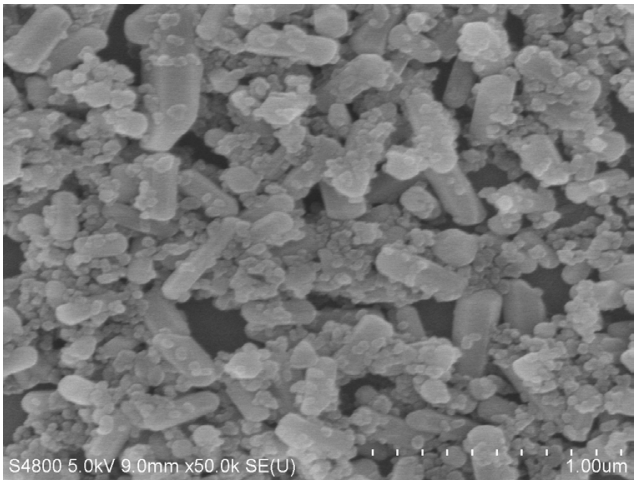

(b)

Figure 2. SEM image of $\mathrm{LiCoPO}_{4}$ synthesized via (a) ST-0.05 and (b) ST-0.025. 


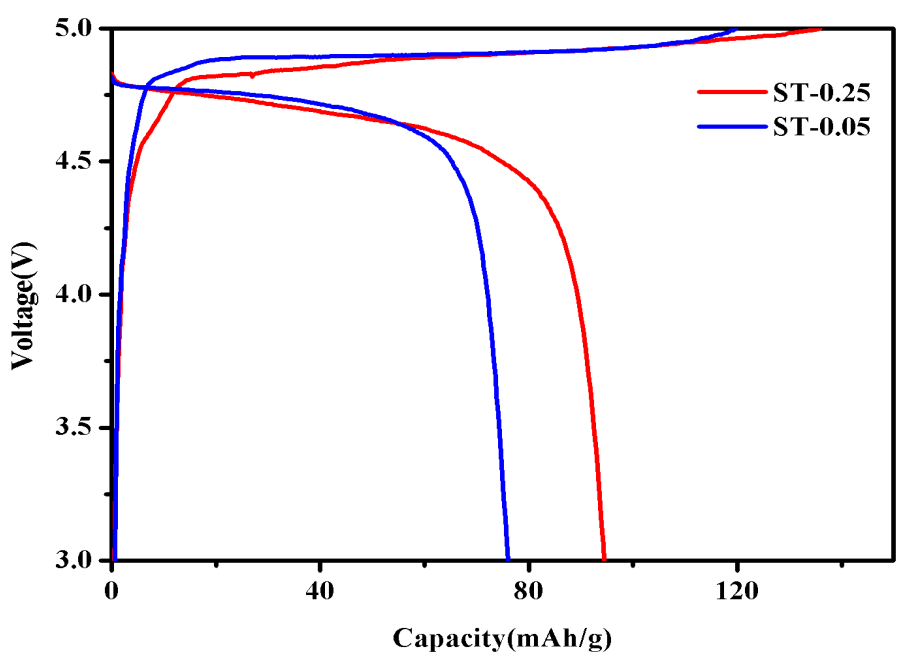

Figure 3. Voltage profiles measured at $0.1 \mathrm{C}$ for the first cycle of the LCP synthesizing by ST-0.05 and ST-0.25.

\section{Conclusion}

In conclusion, the high-voltage cathode material LCP have been synthesized by a sample solvothermal synthesis method using a variety of 1:1 binary solvent blends of deionized water and ethyl alcohol with the different concentration of cobalt ion $(0.05 \mathrm{~mol} / \mathrm{L}, 0.25 \mathrm{~mol} / \mathrm{L})$. Compared to LCP powder synthesizing by ST-0.05, LCP powder synthesizing by ST-0.25 expressed smaller grain, higher discharge capacity and narrower diameter distribution, but easier to produce impurities of metaphosphate. The reason for the lower discharge capacity (94.5 $\mathrm{mAh} / \mathrm{g}$ from ST-0.25) than the theoretical capacity $(167 \mathrm{mAh} / \mathrm{g}) \mathrm{might}$ be the heterogeneous component distribution and temperature, causing the heterogeneous nucleation and growth of LCP crystal particles, finally resulting in wide size distribution and uneven crystals morphology. Furthermore, the $\mathrm{pH}$ value of reaction solvent had the great impact on the crystallization, on account of the different case of ionization for phosphoric acid in different $\mathrm{PH}$ of solvent. Owing to these, we can improve the electrochemical performance of LCP in the following work by doping, changing a strring assisted modified hydrothermal instrument, adding some surfactants to control the morphology of LCP grain and coating carbon. Furthermore, changing a novel method to prepare LCP might bring a better result, such as the sol-gel-hydrothermal method that has the advantages of both sol-gel and hydrothermal synthesis [15], more specifically, the high degree of crystallinity, well-controlled morphology, high purity, and narrow particle size distribution [16] [17].

\section{References}

[1] Amine, K., Yasuda, H. and Yamachi, M. (2000) Olivine $\mathrm{LiCoPO}_{4}$ as $4.8 \mathrm{~V}$ Electrode Material for Lithium Batteries. Electrochemical and Solid State Letters, 3, 178-179. https://doi.org/10.1149/1.1390994

[2] Padhi, A.K., Nanjundaswamy, K.S. and Goodenough, J.B. (1997) Phospho-Olivines 
as Positive-Electrode Materials for Rechargeable Lithium Batteries. Journal of the Electrochemical Society, 144, 1188-1194. https://doi.org/10.1149/1.1837571

[3] Ludwig, J., Marino, C. and Haering, D. (2017) Morphology-Controlled Microwave-Assisted Solvothermal Synthesis of High-Performance $\mathrm{LiCoPO}_{4}$ as a High-Voltage Cathode Material for Li-Ion Batteries. Journal of Power Sources, 350, 103-108. http://www.sciencedirect.com/science/article/pii/S0378775316317554

[4] Wang, Y., He, P. and Zhou, H. (2011) Olivine $\mathrm{LiFePO}_{4}$ : Development and Future. Energy and Environmental Science, 4, 805-817. https://doi.org/10.1039/C0EE00176G

[5] Okada, S., Sawa, S., Egashira, M., Yamaki, J., Tabuchi, M., Kageyama, H., et al. (2001) Cathode Properties of Phospho-Olivine $\mathrm{LiMPO}_{4}$ for Lithium Secondary Batteries. Journal of Power Sources, 97-98, 430-432. https://doi.org/10.1016/S0378-7753(01)00631-0

[6] Amine, K., Yasuda, H. and Yamachi, M. (2000) Olivine $\mathrm{LiCoPO}_{4}$ as $4.8 \mathrm{~V}$ Electrode Material for Lithium Batteries. Electrochemical and Solid State Letters, 3, 178-179. https://doi.org/10.1149/1.1390994

[7] Lloris, J.M., Perez, V.C. and Tirado, J.L. (2002) Improvement of the Electrochemical Performance of $\mathrm{LiCoPO}_{4} 5 \mathrm{~V}$ Material Using a Novel Synthesis Procedure. Electrochemical and Solid State Letters, 5, A234-A237. https://doi.org/10.1149/1.1507941

[8] Gangulibabu, D., Bhuvaneswari, N. and Kalaiselvi, N. (2009) CAM Sol-Gel Synthesized $\mathrm{LiMPO}_{4}(\mathrm{M}=\mathrm{Co}, \mathrm{Ni})$ Cathodes for Rechargeable Lithium Batteries. Journal of Sol-Gel Science and Technology, 49, 137-144. https://doi.org/10.1007/s10971-008-1870-5

[9] Maeyoshi, Y., Miyamoto, S., Noda, Y., Munakata, H. and Kanamura, K. (2017) Effect of Organic Additives on Characteristics of Carbon-Coated $\mathrm{LiCoPO}_{4}$ Synthesized by Hydrothermal Method. Jourmal of Power Sources, 337, 92-99. https://doi.org/10.1016/j.jpowsour.2016.10.106

[10] Ludwig, J., Haering, D., Doeff, M.M. and Nilges, T. (2017) Particle Size-Controllable Microwave-Assisted Solvothermal Synthesis of the High-Voltage Cathode Material $\mathrm{LiCoPO}_{4}$ Using Water/Ethylene Glycol Solvent Blends. Solid State Sciences, 65, 100-109. https://doi.org/10.1016/j.solidstatesciences.2017.01.009

[11] Ludwig, J., Nordlund, D., Doeff, M.M. and Nilges, T. (2017) Synthesis and Characterization of Metastable, 20nm-Sized Pna2.sub.1-LiCoPO.sub.4 Nanospheres. Journal of Solid State Chemistry, 248, 9-17. https://doi.org/10.1016/j.jssc.2017.01.015

[12] Yoshida, J., Nakanishi, S. and Iba, H. (2012) Improvement of Battery Performances of $\mathrm{LiCoPO}_{4}$ as Cathode Material for Lithium Ion Batteries. The Electrochemical Society Meeting, Honolulu, $\mathrm{Hi}, 2012$.

[13] Jin, B., Gu, H.B. and Kim, K.W. (2008) Effect of Different Conductive Additives on Charge/Discharge Properties of $\mathrm{LiCoPO}_{4} / \mathrm{Li}$ Batteries. Journal of Solid State Electrochemistry, 12, 105-111. https://doi.org/10.1007/s10008-007-0367-4

[14] Wang, F. and Yang, J. (2013) Synthesis and Electrochemical Performance of Nano $\mathrm{LiCoPO}_{4}$ by Polyol Method. Journal of Electrochemistry, 19, 585-588.

[15] Chen, Z.W., Zhan, G.H., Wu, Y.P., He, X.H. and Lu, Z.Y. (2014) Sol-Gel-Hydrothermal Synthesis and Conductive Properties of Al-doped ZnO Nanopowders with Controllable Morphology. Journal of Alloys and Compounds, 587, 692-697. https://doi.org/10.1016/j.jallcom.2013.10.241

[16] Hou, Y.D., Hou, L., Huang, S.Y., Zhang, T.T., Zhu, M.K., Wang, H. and Yan, H. (2007) $\left(\mathrm{Na}_{0.8} \mathrm{~K}_{0.2}\right)_{0.5} \mathrm{Bi}_{0.5} \mathrm{TiO}_{3}$ Nanowires: Low-Temperature Sol-Gel-Hydrothermal Synthesis and Densification. Journal of American Ceramic Society, 90, 1738-1743. 
https://doi.org/ 10.1111/j.1551-2916.2007.01657.x

[17] Chen, Z.W. and He, X.H. (2010) Low-Temperature Preparation of Nanoplated Bismuth Titanate Microspheres by a Sol-Gel-Hydrothermal Method. Journal of Alloys Compounds, 497, 312-315. https://doi.org/10.1016/j.jallcom.2010.03.053

Submit or recommend next manuscript to SCIRP and we will provide best service for you:

Accepting pre-submission inquiries through Email, Facebook, LinkedIn, Twitter, etc. A wide selection of journals (inclusive of 9 subjects, more than 200 journals)

Providing 24-hour high-quality service

User-friendly online submission system

Fair and swift peer-review system

Efficient typesetting and proofreading procedure

Display of the result of downloads and visits, as well as the number of cited articles

Maximum dissemination of your research work

Submit your manuscript at: http://papersubmission.scirp.org/

Or contact jpee@scirp.org 